\title{
Owning, letting and demanding second homes
}

\author{
by \\ Gintautas Bloze \\ and \\ Morten Skak
}

Discussion Papers on Business and Economics

No. $1 / 2014$

FURTHER INFORMATION Department of Business and Economics Faculty of Business and Social Sciences University of Southern Denmark

Campusvej 55

DK-5230 Odense M

Denmark

Tel.: +4565503271

Fax: +4565503237

E-mail: lho@sam.sdu.dk

http://www.sdu.dk/ivoe 


\title{
Owning, letting and demanding second homes
}

\author{
Gintautas Bloze ${ }^{\mathrm{a}}$ and Morten Skak ${ }^{\mathrm{b}}$
}

\begin{abstract}
An increasing number of households consume housing beyond the primary home as owners of a second home. Economic studies of second homeownership are still very scarce, and the present empirical study fills this gap to some extent. It is based on Danish survey data combined with administrative register data and presents estimations of the probability of owning a second home, the decision to let the second home and the number of let weeks per year. Also income elasticities for primary and second housing demand are estimated. We find a conventional monotonic increase in demand elasticities for primary housing demand for non-owners of second homes; however, owners of second homes have the highest income elasticity in the middle income group.
\end{abstract}

JEL Classification: D71, D85, R2, Z13

Keywords: Second home, Homeownership, Letting, Income elasticity, Denmark.

a Gintautas Bloze: University of Southern Denmark, Department of Leadership and Corporate Strategy, Sdr. Stationsvej 28, DK-4200 Slagelse, Denmark.

b Corresponding author Morten Skak: E-mail mos@sam.sdu.dk. University of Southern Denmark, Department of Business and Economics, Campusvej 55, DK-5230 Odense M, Denmark. 


\section{Introduction}

Increasing real incomes naturally lead to increased demand for housing, and this may take the form of a second home, i.e. a summer cottage, a condominium in a city, a share in a timeshare arrangement, etc. Recent estimates of second homeownership rates vary between 2 and 14 per cent in Europe and the United States (McIntyre et al., 2006; Belsky et al., 2007). With a growing number of second homes, it becomes increasingly important for planners of land and public infrastructure, actors in the building industry, and economists to know which factors influence the demand for second as well as primary homes. It is equally important to know what influences second homeowners' inclination to let their homes and thereby increase the annual occupation of the homes. While studies of the demand for primary housing are numerous, our literature review below shows that few studies have focused on second housing. A small number of papers study the determinants for owning a second home; others look at the impact of second housing on tourism, taxation, and production. In addition, we have found two papers on the pricing of second home rentals and one on the decision not to let a second home. Two papers based on the American Housing Survey and the Survey of Consumer Finances focus on the income elasticity of housing demand with the inclusion of second housing. Our study seeks determinants for the decision to own a second home, to let the home, how many weeks to let the home and, finally, the income elasticity of demand for primary and second housing. It is based on a survey among 2386 Danish households combined with the Danish administrative data. Close to one fifth of the respondents declare that they own one or more second homes.

We find a positive association between ownership of a second home and the age of the breadwinner, marriage and cohabitation, and household income. The probability for letting the second home is lower for older breadwinners and higher household income, and is also lower among those who rent their primary home. Factors that seem to affect the annual number of weeks let relate more to the characteristics of the second home. Thus, second apartments and homes with joint ownership are let for more weeks than single-owned summer cottages. Older second homes and those with a high loan to value rate are let for more weeks. 
Our analysis of income elasticities shows that owners of primary homes who also own second homes have different income elasticities for housing demand compared to primary owners without second homes. While we find the conventional monotonic increase in demand elasticities for primary housing demand for non-owners of second homes, owners of second homes have the highest income elasticity in the middle income group.

The paper is structured as follows. We start with a literature review in the next section and a short description of the Danish second house sector in section three. Section four describes our data, and section five seeks answers to the question: To own or not to own a second home? Whether to let or not to let the second home is the research subject in section six, and how many weeks to let is the subject in section seven. A number of estimates of income elasticities of housing demand are presented in section eight, after which section nine presents our conclusions.

\section{Literature review}

Second and recreational housing has mostly been studied by sociologically inclined tourism researchers and social geographers. An overview of the literature and the different forms of second housing in the developed world can be found in the recent paper by Marcouiller et al. (2013). Economic literature on second housing is sparse compared to the literature on primary housing. But second housing is of great economic importance in many regions, both because of the housing supply it represents and because of its effect on other parts of the economy. Cho et al. (2003) use a hedonic price model to study how the presence of second homes impacts on house prices in rural and urban settings in the Blue Ridge province of the Southern Appalachian Highlands. On average, they found a 1.7 per cent price increase of the value of homes, but the effect is mainly found in the rural communities. Torres and Dominguez-Menchero (2006) use data from Málaga on the Costa del Sol, and Alicante on the Costa Blanca in Spain to estimate the effect of second homes on the tax pressure on locals. Second home tourism requires more public services and creates more production in an area. A positive association between the number of second homes and tax pressure is only found among municipalities with less than 2000 second homes. It disappears for higher concentrations of second homes. Guisan and Aguayo (2010) present statistics on the development of second housing and tourism in Spanish provinces and find a positive relation between this and various production measures. Likewise, but at the micro level, 
Hoogendoorn and Visser (2010) study the impact of second homes on the local economic development based on five case studies in South Africa. Huang and Yi (2011) explain the special case of China, where primary and second homeownership have increased in a society that has changed into a market-oriented economy but still bears a legacy from earlier times, which gives an inefficient distribution of housing. They employ a logistic regression to model second home ownership and find positive associations for, for example, household size and income, being a migrant, being a party member, having parent as household head, being employed in a private firm, and living in a privately rented primary home.

Spain is the case for Modenes Cabrerizo and Colas (2007), who apply logistic regression to estimate second home ownership relations. Homeownership is shown to be positively related to car ownership, the age of the household reference person and the number of floors of the apartment building containing the primary residence. Second homeownership is most common for households living in high-rise multifamily dwellings in densely populated areas. This contrasts with our Danish case where second homeownership is slightly more common among households in detached single-family dwellings. Two papers by Salo and Garriga (2011) and Salo et al. (2012) study the pricing of second home rentals and hotels in the Costa Brava region. Salo and Garriga (2011) use the weekly price for second home rentals as dependent variable and demonstrate how this variable varies with the number of rooms, the size in square meters, the distance to the beach, etc. It is also shown that wholesalers are able to charge a higher price than direct or retail sellers. In Salo et al. (2012) it is shown that prices for second home rentals display a smoother seasonal pattern than hotel prices for a week's stay.

Belsky et al. (2007) use data from the 1995 American Housing Survey and the 2004 Survey of Consumer Finances to model second home demand and the permanent income elasticity of housing demand. Their dependent variable is house value, and the results show A) that the likelihood of owning a second home increases with income, wealth, and age, B) that the income elasticities for primary housing demand are lower for owners of second homes, and C) that the income elasticities for all housing among second home owners are lower than the income elasticity for primary housing alone. Di (2009) uses the same data as Belsky et al. (2007) and adds to the Belsky study that the income elasticities for primary housing demand are not lower for owners of second homes when recent movers are taken into account. 
The study by Bieger et al. (2007) belongs more to the sociological than the economic literature. It is based on a self-administered questionnaire sent out to 3941 non-letting owners in Switzerland and gives a description of the characteristics of these owners. Older owners and owners who purchased their second homes in later periods seem more flexible and more inclined to let their second homes. We find similar results based on our Danish survey data.

\section{Second homes in Denmark}

Statistics Denmark counts 220,448 summer cottages in Denmark ${ }^{1}$ in 2012, of which approximately 98 per cent are privately owned. Between 3 and 8 per cent of these are traded annually. The trading volume has been low after the 2007 financial crisis and the bursting of the price bubble. 70 to 80 per cent of the traded units change owners in ordinary non-family related trading.

Many Danish holiday homes, which include summer cottages, condominiums, time share apartments, etc., are let to tourists and are an essential part of the Danish tourism industry. The tenants are primarily Germans, who take around 70 per cent of the weeks, followed by Danes, who take around 20 per cent, and the rest are mainly divided between Scandinavian and Dutch tourists. The annual number of weeks during which summer cottages are rented out surpasses 2 million and oscillates around 16 million person-nights per year according to figures published by Statistics Denmark. The actual numbers are probably somewhat higher because some letting is not reported to official authorities. While the long-term trend for the number of weeks let has been increasing, it peaked in 2007 and dropped in 2008 and 2009, but has since recovered.

\section{Data description}

The survey data used in this study were randomly collected by an online survey directed at breadwinners $^{2}$ in Danish households with follow-up telephone interviews for nonrespondents. The data were collected in the midsummer of 2012 with a final response rate of

\footnotetext{
${ }^{1}$ The number of all types of Danish dwellings, empty and occupied, was slightly below 3 million in 2012. The population is 5.6 million.

${ }^{2}$ Breadwinners are the highest income earners in the household.
} 
67 per cent and covering 2386 breadwinners of age 26 to 87 . The aim of the survey was to reveal the economic picture for households and not for the individual respondent when cohabitation occurred. To obtain this, one of the first questions in the survey was "Are you married or do you have a cohabitating partner?" A yes to this question prompted questions like "How many second dwellings do you and/or your cohabitating partner have?" Questions relating to second homes were only a part of the bigger number of questions in the survey. The core subject of the survey was the economic situation of Danish homeowners, and homeowners were overrepresented in the survey because of this.

Nineteen per cent of the 2386 households, i.e. 446 households, declared that they have one or more second homes in Denmark. ${ }^{3}$ There are three categories of tenancy for the primary home, i.e. homeownership, cooperative ownership ${ }^{4}$, and renting. Table 1 shows the distributions of the households with second homes by the three categories.

\section{Table 1: Households with second homes}

\begin{tabular}{lccc}
\hline \hline $\begin{array}{l}\text { Tenancy of } \\
\text { primary home }\end{array}$ & $\begin{array}{c}\text { Households with } \\
\text { second homes }\end{array}$ & $\begin{array}{c}\text { Households letting } \\
\text { second homes }\end{array}$ & $\begin{array}{c}\text { Percentage letting } \\
\text { second homes }\end{array}$ \\
\hline Homeowner & 369 & 144 & 39.0 \\
Coop ownership & 21 & 5 & 23.8 \\
Tenant & 53 & 17 & 32.1 \\
Unknown & 3 & 1 & - \\
\hline Total & 446 & 167 & 37.4 \\
\hline
\end{tabular}

Notes: Three respondents do not report the type of the primary home.

Source: Data from a survey conducted in the midsummer of 2012.

Homeowners seem most inclined to let their second home, while coop owners seem most reluctant. Table 2 compares the age and income of owners of second homes with all the households in the survey.

\footnotetext{
${ }^{3}$ In addition, 177 respondents declare that they have (part in) one or more commercial dwellings and/or second homes outside Denmark. No information on these dwellings was collected.

${ }^{4}$ Coop owners own a share of the cooperative association and have the right to rent a specific apartment to a rent below the free market rent. They are regarded as tenants in Denmark.
} 
Table 2: Age and income of households with second homes

\begin{tabular}{llcc}
\hline \hline $\begin{array}{l}\text { Tenancy of } \\
\text { primary home }\end{array}$ & All & $\begin{array}{l}\text { Mean age of } \\
\text { breadwinner }\end{array}$ & $\begin{array}{c}\text { Median annual household income } \\
\text { in DKK }\end{array}$ \\
\hline Homeowner & With sec. home & 50.0 & 588,000 \\
& All & 50.5 & 600,000 \\
\hline \multirow{2}{*}{ Coop ownership } & 48.0 & 369,000 \\
& With sec. home & 55.0 & 401,328 \\
\hline \multirow{2}{*}{ Tenant } & All & 55.0 & 273,000 \\
& With sec. home & 504,000 \\
\hline \hline
\end{tabular}

Notes: Household income is the breadwinner's income plus the income of this person's spouse or cohabitating partner.

Source: Data from a survey conducted in the midsummer of 2012.

Homeowners with second homes are on average older than other primary homeowners, but this tendency is not found among coop owners and tenants. However, the median income of owners of second homes is higher than the median income in all the three primary tenancy groups.

Table 3: Types and letting of second homes

\begin{tabular}{llccc}
\hline \hline $\begin{array}{l}\text { One or more second } \\
\text { homes }\end{array}$ & Type of second home & Total & $\begin{array}{l}\text { Number of } \\
\text { owners who let }\end{array}$ & $\begin{array}{l}\text { Percentage } \\
\text { letting }\end{array}$ \\
\hline One second home & $\begin{array}{l}\text { Summer cottage } \\
\text { Apartment }\end{array}$ & 308 & 79 & 25.6 \\
& $\begin{array}{l}\text { Joint ownership and } \\
\text { timeshare }\end{array}$ & 58 & 41 & 70.1 \\
\hline More second homes & & 67 & 39 & 34.7 \\
\hline \hline
\end{tabular}

Note: The table shows the number of households.

Source: Data from a survey conducted in the midsummer of 2012.

The typical Danish second home is a summer cottage or a country house, but it can also be an apartment or a dwelling with various kinds of shared ownership. Summer cottages most commonly have wooden exterior walls, and brick walls are the second most common. Letting of second homes that are apartments is very common (see table 3 ) and 25 per cent of second homes with joint ownership are let, while only around one fourth of summer cottages are let. The survey was conducted at a time when house prices were at the bottom after a longer 
downturn, and trading volumes were low. We reckon, as a consequence of this, that a number of the second homes are let because the owners do not want to sell at the going prices, but rather prefer to wait for better prices and put second homes on the rental market in the meantime. In these cases, ownership is not the result of a demand for the housing services provided by the home, but a financial investment, which is considered to give the best return by letting now and selling later. We have no information that reveals the different motives that the owners have for their ownership of a second home, but the investment motive is no doubt most pronounced when the second home is an apartment as opposed to a summer cottage. We have conducted a number of regressions on ownership of summer cottages alone and report below when these regressions depart from the ones including owners of all kinds of second homes.

More than half of the households in the survey with more than one second home let one or more of these. 45 per cent of the let second homes are let directly, while the rest are let through an agency.

Those who let were asked: “Approximately how many weeks is the second home let?" The answers range from three weeks to the whole year. When the reported approximate ${ }^{5}$ annual rent is divided by the number of weeks, a mean rent per week of 2046 DKK appears. ${ }^{6}$

The survey data have been merged with the Danish administrative data containing information about dwelling characteristics. However, data on, for example, the living area and the building year of a second home have only been collected for households with one second home because we are unable to identify which one of the second homes that is let in cases where the household owns more than one second home. The merging of data is subject to some uncertainty because of time variation between the collection of register data and the survey time. Some owners may have sold or bought second homes in the months between the register time ${ }^{7}$ and the survey time; and other important variables may also have changed. In spite of this, we believe that the data we use create a reliable picture of the relations in the

\footnotetext{
${ }^{5}$ The word approximately is used in the questionnaire to smooth over actual swings in letting because of low demand in a year, few weeks of letting because of renovations, etc.

${ }^{6}$ This is equivalent to around 275 euros per week at the time of the survey.

${ }^{7}$ Register time for stock variables is very often the beginning or end of a year. In our case, the administrative register data contain information from the end of 2011 or the beginning of 2012.
} 
sector. Table 4 gives an overview of the statistics for households with second homes, while table A1 in the appendix gives summary statistics for all households in the survey.

Table 4: Summary statistics for households with second homes

\begin{tabular}{|c|c|c|c|c|}
\hline Variable & Mean & Min & Max & Observations \\
\hline Age of breadwinner & 56.78 & 26 & 86 & 446 \\
\hline Annual household income in DKK & 736,223 & 60,000 & $6,600,000$ & 399 \\
\hline Owner of primary home & 0.83 & 0 & 1 & 443 \\
\hline Coop owner of primary home & 0.05 & 0 & 1 & 443 \\
\hline Tenant of primary home & 0.12 & 0 & 1 & 443 \\
\hline Number of second homes & 1.20 & 1 & 8 & 446 \\
\hline Living area of second home ${ }^{\text {a) }}$ & 83.25 & 12 & 600 & 404 \\
\hline Building year of second home & 54.29 & 1 & 235 & 404 \\
\hline \multicolumn{5}{|l|}{$\begin{array}{l}\text { The following descriptives are based } \\
\text { on households owning one second home: }\end{array}$} \\
\hline Summer cottage & 0.81 & 0 & 1 & 379 \\
\hline Apartment & 0.14 & 0 & 1 & 379 \\
\hline Timeshare, etc. & 0.05 & 0 & 1 & 379 \\
\hline Second home is in different region & 0.30 & 0 & 1 & 341 \\
\hline Second home is in town/city & 0.11 & 0 & 1 & 341 \\
\hline Loan-to-value ratio for second homes & 0.42 & 0 & 1.58 & 354 \\
\hline LTV: 0 & 0.26 & 0 & 1 & 354 \\
\hline LTV: 0.01 to .50 & 0.33 & 0 & 1 & 354 \\
\hline LTV: 0.51 to 0.80 & 0.29 & 0 & 1 & 354 \\
\hline LTV: 0.81 to $\max$ & 0.12 & 0 & 1 & 354 \\
\hline Second home is let & 0.34 & 0 & 1 & 377 \\
\hline Number of weeks let ${ }^{\text {b) }}$ & 35.7 & 3 & 52 & 123 \\
\hline Rent per week & 1870.8 & 0 & 6000 & 120 \\
\hline
\end{tabular}

Notes: The table shows variables that are used in the regressions in the paper. a) Living area has been cleaned for extreme values. b) Statistics for owners who let.

Source: Data from a survey conducted in the midsummer of 2012 and administrative register data. 


\section{To own or not to own a second home}

In this section we study the characteristics of households who are owners of one or more second homes by applying logistic regressions. Table 5 reports odds ratios (OR) from these regressions. ${ }^{8}$

Table 5: Logistic regression of owning a second home

\begin{tabular}{|c|c|c|c|c|}
\hline \multirow{3}{*}{ Variable } & \multirow{3}{*}{$\begin{array}{c}\text { All } \\
\text { households } \\
\begin{array}{c}\text { Odds ratio } \\
\text { (z values) }\end{array}\end{array}$} & \multicolumn{3}{|c|}{ Primary } \\
\hline & & \multicolumn{2}{|c|}{ homeowners } & \multirow{2}{*}{$\begin{array}{c}\text { other }^{\mathrm{a})} \\
\text { Odds } \\
\text { ratio } \\
\text { (z values) }\end{array}$} \\
\hline & & $\begin{array}{l}\text { Odds ratio } \\
\text { (z values) }\end{array}$ & $\begin{array}{l}\text { Odds ratio } \\
\text { (z values) }\end{array}$ & \\
\hline \multicolumn{5}{|c|}{ Reference is age of breadwinner up to 35} \\
\hline Age 36 to 49 & $\begin{array}{c}1.40 \\
(1.47)\end{array}$ & $\begin{array}{l}1.57 * \\
(1.63)\end{array}$ & $\begin{array}{c}1.59 \\
(1.61)\end{array}$ & $\begin{array}{c}1.13 \\
(0.27)\end{array}$ \\
\hline Age 50 to 64 & $\begin{array}{c}4.29 * * * \\
(6.56)\end{array}$ & $\begin{array}{c}6.36 * * * \\
(1.72)\end{array}$ & $\begin{array}{c}5.79 * * * \\
(6.03)\end{array}$ & $\begin{array}{c}1.39 \\
(0.73)\end{array}$ \\
\hline Age $65+$ & $\begin{array}{c}7.03^{* * *} * \\
(8.04)\end{array}$ & $\begin{array}{c}11.37 * * * \\
(8.15)\end{array}$ & $\begin{array}{c}10.55 * * * \\
(7.29)\end{array}$ & $\begin{array}{c}2.09 \\
(1.62)\end{array}$ \\
\hline Married or cohabitating & $\begin{array}{c}2.34 * * * \\
(5.10)\end{array}$ & $\begin{array}{c}2.22 * * * \\
(4.08)\end{array}$ & $\begin{array}{c}2.01 * * * \\
(3.23)\end{array}$ & $\begin{array}{l}1.96 * * \\
(2.04)\end{array}$ \\
\hline Children & $\begin{array}{c}0.83 * * * \\
(-2.17)\end{array}$ & $\begin{array}{c}0.87 \\
(-1.46)\end{array}$ & $\begin{array}{c}0.84^{*} \\
(-1.68)\end{array}$ & $\begin{array}{c}1.01 \\
(0.07)\end{array}$ \\
\hline \multicolumn{5}{|c|}{ Reference is first quartile group of household income ${ }^{\mathrm{b})}$} \\
\hline Second quartile group & $\begin{array}{c}1.65^{* * * *} \\
(2.59)\end{array}$ & $\begin{array}{l}1.49 * \\
(1.79)\end{array}$ & $\begin{array}{l}1.45 \\
(1.47)\end{array}$ & $\begin{array}{c}1.92 \\
(1.64)\end{array}$ \\
\hline Third quartile group & $\begin{array}{c}2.40 * * * \\
(4.15)\end{array}$ & $\begin{array}{c}2.17 * * * \\
(3.31)\end{array}$ & $\begin{array}{c}2.31 * * * \\
(3.14)\end{array}$ & $\begin{array}{c}4.50 * * * \\
(3.30)\end{array}$ \\
\hline Forth quartile group & $\begin{array}{c}3.48 * * * \\
(5.75)\end{array}$ & $\begin{array}{c}3.75 * * * \\
(5.42)\end{array}$ & $\begin{array}{c}3.74 * * * \\
(4.77)\end{array}$ & $\begin{array}{l}2.53^{*} \\
(1.81)\end{array}$ \\
\hline Owner of primary home & $\begin{array}{l}1.61 * * \\
(2.35)\end{array}$ & & & \\
\hline \multicolumn{5}{|c|}{ Reference is primary education of breadwinner } \\
\hline Vocational education & $\begin{array}{c}1.88 * * * \\
(3.57)\end{array}$ & $\begin{array}{c}1.93 * * * \\
(3.27)\end{array}$ & $\begin{array}{c}1.96^{* * * *} \\
(3.02)\end{array}$ & $\begin{array}{l}1.95 * \\
(1.72)\end{array}$ \\
\hline Lower tertiary education & $\begin{array}{c}1.82 * * * \\
(2.97)\end{array}$ & $\begin{array}{c}1.82 * * * \\
(2.62)\end{array}$ & $\begin{array}{l}1.71 * * \\
(2.16)\end{array}$ & $\begin{array}{c}1.71 \\
(1.18)\end{array}$ \\
\hline Higher tertiary education & $\begin{array}{c}2.54 * * * \\
(4.14)\end{array}$ & $\begin{array}{c}2.12 * * * \\
(2.94)\end{array}$ & $\begin{array}{c}2.14 * * * \\
(2.82)\end{array}$ & $\begin{array}{c}3.44 * * * \\
(2.50)\end{array}$ \\
\hline
\end{tabular}

\footnotetext{
${ }^{8}$ Regressions for ownership of a summer cottage alone give similar results.
} 


\begin{tabular}{|c|c|c|c|c|}
\hline $\begin{array}{l}\text { Primary home is in a high-rise } \\
\text { building }\end{array}$ & $\begin{array}{c}1.76 * * * \\
(2.86)\end{array}$ & $\begin{array}{c}2.13 * * * \\
(3.02)\end{array}$ & $\begin{array}{c}2.14 * * * \\
(2.82)\end{array}$ & $\begin{array}{c}1.15 \\
(0.45)\end{array}$ \\
\hline \multicolumn{5}{|c|}{ Reference is LTV for primary home $<.80$} \\
\hline LTV: 0.80 to 1 & - & - & $\begin{array}{c}1.06 \\
(0.35)\end{array}$ & \\
\hline LTV: 1 to 1.20 & - & - & $\begin{array}{c}0.65 \\
(-1.56)\end{array}$ & \\
\hline LTV: above 1.20 & - & - & $\begin{array}{c}0.91 \\
(-0.23)\end{array}$ & \\
\hline Constant & $\begin{array}{l}0.01 * * * \\
(-13.51)\end{array}$ & $\begin{array}{l}0.01 * * * \\
(-12.08)\end{array}$ & $\begin{array}{l}0.01 * * * \\
(-10.33)\end{array}$ & $\begin{array}{l}0.02 * * * \\
(-6.34)\end{array}$ \\
\hline Number of observations & 2087 & 1553 & 1302 & 534 \\
\hline $\mathrm{LR} \mathrm{Chi}^{2}$ & $264.04 * * *$ & $234.21 * * *$ & $197.74 * * *$ & $39.69 * * *$ \\
\hline Pseudo $\mathrm{R}^{2}$ & 0.13 & 0.15 & 0.15 & 0.10 \\
\hline
\end{tabular}

Notes: a) Coop owners and tenants. b) See table A1 in the appendix for the cutoff values.

Source: Data from a survey conducted in the midsummer of 2012 and administrative register data.

The first observation is that older households (households with an older breadwinner) have a significantly higher probability of being owner of a second home. Also marriage and cohabitation increase the likelihood for ownership of a second home, while the converse is true for having children. Being in the third or fourth quartiles with respect to household income significantly increases the propensity for owning a second home, and the probability of second homeownership is significantly higher for owners of primary homes as opposed to other types of primary tenancy.

Vocational and tertiary education significantly increases the odds for being a second homeowner. The firm association between second homeownership and educational attainment may be taken as an indicator of a positive relation between permanent income and second homeownership. Living in an apartment in a high-rise building ${ }^{9}$ increases the likelihood of owning a second home among the primary homeowners. This result seems plausible: living in urban high-rise buildings should increase the wish for owning a recreational site with a summer cottage somewhere outside the cities. Including the loan-tovalue-ratio (LTV) for the primary home in the regression does not have an impact on the other coefficients and shows no association with second homeownership. A higher LTV of the primary home may be thought to reduce the ability to borrow money for a second home, i.e. the odds ratios are lower for higher levels of primary LTV, but this is not confirmed by

\footnotetext{
${ }^{9} 70$ per cent of coop owners and tenants live in high-rise buildings.
} 
the last LTV level indicator, which turned to be close to 1 and insignificant. An explanation of the unclear result can be the opposite relationship, as mortgage in the primary housing may be taken to finance the acquisition of a second home.

The regressions for primary homeowners, coop owners and tenants do not deviate much from each other. One difference is, however, that having higher educational attainment seems more important for primary coop owners and tenants than for homeowners. The lacking significance for some odds ratios for primary coop owners and tenants may be attributed to a reduced number of observations.

\section{To let or not to let}

Most of the demand for Danish let second housing comes from Germany that has a population 15 times the population of Denmark. However, only EU citizens with a record of five years' permanent primary home address in Denmark are allowed to buy second homes in the country. Thus, renting is the only possibility for consumption for nearly all non-citizens.

What are the characteristics of the households who let their second home? We have run a regression confirming that the probability of letting is positively associated with the number of owned second homes. But we are unable to detect which of the second homes that are let in cases where there is ownership of more than one second home. In order to be able to include housing characteristics among the explanatory variables, we present four logistic regressions for households with only one second home in table 6 , where we also focus on summer cottages alone, because the ownership and letting of other types of second homes might be motivated by financial incentives.

Table 6: Logistic regressions for the letting of second homes

\begin{tabular}{|c|c|c|c|c|}
\hline & \multicolumn{2}{|c|}{ All second homes } & \multicolumn{2}{|c|}{ Only summer cottages } \\
\hline Variable & $\begin{array}{c}\text { Odds ratio } \\
\text { (z values) }\end{array}$ & $\begin{array}{c}\text { Odds ratio } \\
\text { (z values) }\end{array}$ & $\begin{array}{c}\text { Odds ratio } \\
\text { (z values) }\end{array}$ & $\begin{array}{l}\text { Odds ratic } \\
\text { (z values) }\end{array}$ \\
\hline \multicolumn{5}{|c|}{ Reference is age of breadwinner up to 35} \\
\hline Age 36 to 49 & $\begin{array}{c}0.41 \\
(-1.62)\end{array}$ & $\begin{array}{c}0.63 \\
(-0.80)\end{array}$ & $\begin{array}{c}0.66 \\
(-0.61)\end{array}$ & $\begin{array}{c}0.87 \\
(-0.20)\end{array}$ \\
\hline Age 50 to 64 & $\begin{array}{c}0.15 * * * \\
(-3.51)\end{array}$ & $\begin{array}{l}0.29 * * \\
(-2.19)\end{array}$ & $\begin{array}{c}0.27 * * \\
(-1.87 *)\end{array}$ & $\begin{array}{c}0.43 \\
(-1.19)\end{array}$ \\
\hline
\end{tabular}




\begin{tabular}{|c|c|c|c|c|}
\hline Age $65+$ & $\begin{array}{c}0.14 * * * \\
(-3.52)\end{array}$ & $\begin{array}{c}0.24 * * * \\
(-2.46)\end{array}$ & $\begin{array}{l}0.25 * * \\
(-1.98)\end{array}$ & $\begin{array}{c}0.34 \\
(-1.49)\end{array}$ \\
\hline Married or cohabitating & $\begin{array}{l}1.38 \\
(0.75)\end{array}$ & $\begin{array}{l}1.25 \\
(0.49)\end{array}$ & $\begin{array}{l}1.00 \\
(0.01)\end{array}$ & $\begin{array}{l}1.04 \\
(0.09)\end{array}$ \\
\hline Children & $\begin{array}{c}0.80 \\
(-1.04)\end{array}$ & $\begin{array}{c}0.91 \\
(-0.42)\end{array}$ & $\begin{array}{c}0.98 \\
(-0.08)\end{array}$ & $\begin{array}{c}1.04 \\
(0.16)\end{array}$ \\
\hline \multicolumn{5}{|c|}{ Reference is first quartile group of household income ${ }^{\mathrm{a}}$} \\
\hline Second quartile group & $\begin{array}{c}0.63 \\
(-1.06)\end{array}$ & $\begin{array}{c}0.46 \\
(-1.62)\end{array}$ & $\begin{array}{c}0.82 \\
(-0.38)\end{array}$ & $\begin{array}{c}0.62 \\
(-0.92)\end{array}$ \\
\hline Third quartile group & $\begin{array}{c}0.42^{*} \\
(-1.80)\end{array}$ & $\begin{array}{l}0.41^{*} \\
(-1.75)\end{array}$ & $\begin{array}{c}0.51 \\
(-1.23)\end{array}$ & $\begin{array}{c}0.46 \\
(-1.36)\end{array}$ \\
\hline Forth quartile group & $\begin{array}{c}0.63 \\
(-0.95)\end{array}$ & $\begin{array}{c}0.47 \\
(-1.44)\end{array}$ & $\begin{array}{c}0.58 \\
(-0.95)\end{array}$ & $\begin{array}{c}0.43 \\
(-1.41)\end{array}$ \\
\hline Owner of primary home & $\begin{array}{l}2.91 * * \\
(2.28)\end{array}$ & $\begin{array}{l}2.34 * \\
(1.75)\end{array}$ & $\begin{array}{l}2.63 * \\
(1.74)\end{array}$ & $\begin{array}{c}2.23 \\
(1.41)\end{array}$ \\
\hline \multicolumn{5}{|c|}{ Reference is living area of second home $<70$ square meters } \\
\hline $\begin{array}{l}\text { Living area } 70 \text { to } 110 \\
\text { square meters } \\
\text { Living area above } 110 \\
\text { square meters }\end{array}$ & $\begin{array}{c}2.55^{* * * *} \\
(2.99) \\
4.14 * * * \\
(3.68)\end{array}$ & $\begin{array}{c}2.43 * * * \\
(2.59) \\
3.73 * * * \\
(3.23)\end{array}$ & $\begin{array}{c}2.84 * * * \\
(2.85) \\
4.44 * * * \\
(3.41)\end{array}$ & $\begin{array}{c}2.37 * * * \\
(2.26) \\
3.60 * * * \\
(2.82)\end{array}$ \\
\hline $\begin{array}{l}\text { Second home in different } \\
\text { region }\end{array}$ & $\begin{array}{c}0.70 \\
(-1.21)\end{array}$ & $\begin{array}{c}0.74 \\
(-0.92)\end{array}$ & $\begin{array}{c}0.64 \\
(-1.21)\end{array}$ & $\begin{array}{c}0.71 \\
(-0.91)\end{array}$ \\
\hline Second home in town/city & $\begin{array}{c}6.39 * * * \\
(3.97)\end{array}$ & $\begin{array}{c}5.07 * * * \\
(3.11)\end{array}$ & - b) & - b) \\
\hline \multicolumn{5}{|c|}{ Reference is LTV for second home $=0$} \\
\hline LTV $0-0.4$ & - & $\begin{array}{l}2.59 * * \\
(2.06)\end{array}$ & - & $\begin{array}{l}2.38 * \\
(1.76)\end{array}$ \\
\hline LTV $0.4-0.8$ & - & $\begin{array}{l}4.38 * * * \\
(3.10)\end{array}$ & - & $\begin{array}{l}3.24 * * \\
(2.27)\end{array}$ \\
\hline LTV $>0.8$ & - & $\begin{array}{c}7.55^{* * *} \\
(3.49)\end{array}$ & - & $\begin{array}{c}4.93 * * * \\
(2.33)\end{array}$ \\
\hline Constant & $\begin{array}{c}0.58 \\
(-0.85)\end{array}$ & $\begin{array}{l}0.18 * * \\
(-2.19)\end{array}$ & $\begin{array}{c}0.33 \\
(-1.33)\end{array}$ & $\begin{array}{l}0.15 * * \\
(-2.04)\end{array}$ \\
\hline Number of observations & 306 & 296 & 249 & 245 \\
\hline $\mathrm{LR} \mathrm{Chi}^{2}$ & $62.95 * * *$ & $74.60 * * *$ & $27.67 * * *$ & $33.75^{* * * *}$ \\
\hline Pseudo $\mathrm{R}^{2}$ & 0.16 & 0.20 & 0.10 & 0.12 \\
\hline
\end{tabular}

Note: a) See table A1 in the appendix for the cutoff values. b) Summer cottages are located in the countryside. Source: Data from a survey conducted in the midsummer of 2012 and administrative register data.

Table 1 above revealed that the percentage of households that let is lower among primary tenants and coop owners than among primary homeowners. Our assumption behind the regressions in table 6 is that the differences between primary homeowners and primary tenants and coop owners can be captured by a dummy for homeownership. 
Looking first at the two regressions first, where all second homes are included, we find that older households are least likely to let their second homes, indicating that they use their second homes more than the younger households. While marriage and cohabitation had a significant positive association with ownership of a second home, there is no such association here, and neither is there any firm association with children in the household. Big second homes are more likely to be let. A number of the big summer cottages are equipped with spa baths, etc., and the potential income from letting is typically included in the estate agents' particulars for the big second homes.

We saw in table 5 that a high income increases the probability for ownership, while table 6 demonstrates that the association with letting is weak but points towards a reduced tendency for letting summer cottages for high incomes. The last relation seems reasonable as consumption of normal goods - in this case summer cottage housing - increases with higher income.

Ownership of the primary home has a significant positive association with letting. Higher LTV rates for the second home have a very strong positive effect on letting, indicating that households try to relieve their mortgage repayments by letting out the second homes.

A distant location of the second compared to the primary home does not affect the probability of letting. There were no prior exceptions to this variable, which acted as a proxy for distance. The location of the second home in a town or city is positively associated with a high propensity for letting, most likely because apartments are typically located in urban areas, where letting is much easier throughout the year. Another explanation is that many owners of second homes did not want to sell in the sluggish market with low housing prices in 2012, but preferred to wait for better prices and let the second homes in the meantime. This financial motive for ownership is presumably most pronounced for ownership of apartments in urban areas and less dominant for owners of summer cottages in rural areas.

The last two regressions in table 6 are done for summer cottages only and show some differences compared to the first two regressions. Ownership of the primary home has no positive association with letting in the case where LTV rates are included. The association between the LTV and letting observed in the two first regressions is weaker for summer cottages, presumably because the relation in the first two regressions was enhanced by the letting of apartments. Many of those were bought when the house prices peaked in 2006. 
With a low demand for ownership in 2012, letting was an attractive option under the Danish full recourse mortgage system.

\section{How many weeks to let}

Having studied the question of whether or not to let, our next natural question concerning those who have decided to let is how many weeks they let - or what relations can be found between the number of weeks let and the characteristics of the households and of the second homes?

The formulations of the questionnaire may have produced a minor lack of precision of the answers. After having answered yes to the question: "Is the second home let?" respondents are asked: "How many weeks per year is the home approximately let?" We cannot exclude that a few owners include their own renting of the home ${ }^{10}$ in the reported number of weeks let, and this may have biased our analysis.

The results of two OLS regressions are shown in columns two and three in table 7. Note that the number of observations is considerably lower now because only letting households with one second home are included. The fewer observations can make it more difficult to reach significance for the coefficients.

The age of the households proxied by the age of the breadwinner only reaches significance for the age group 36 to 49 . This group is probably characterized by a high number of working hours. Marriage and cohabitation are positively associated with the number of weeks let, but the relation loses significance in the second regression where the rent is included. The negative relation between household income and the number of weeks let is as expected, but it does not reach significance. Primary homeowners tend to let for more weeks than nonowners, and older second homes are let for more weeks. Second apartments and homes with joint ownership or timeshare are let for more weeks than summer cottages. Large second homes are let for more weeks. The location of the second home in a region different from the region of the primary home has no significant effect, whereas the location of the second home in a town increases the number of weeks let. The number of weeks let is also positively related to the LTV of the second home.

\footnotetext{
${ }^{10}$ This may especially be the case for second joint ownership and timeshare.
} 
Table 7: OLS regressions and a tobit regression of the number of weeks let per year

\begin{tabular}{|c|c|c|c|}
\hline $\begin{array}{l}\text { Type of regression } \\
\text { Variable }\end{array}$ & $\begin{array}{c}\text { OLS } \\
\text { Coefficient } \\
\text { (t values) }\end{array}$ & $\begin{array}{c}\text { OLS } \\
\text { Coefficient } \\
\text { (t values) }\end{array}$ & $\begin{array}{c}\text { TOBIT } \\
\text { Coefficient } \\
\text { (t values) }\end{array}$ \\
\hline \multicolumn{4}{|l|}{ Reference is age of breadwinner up to 35} \\
\hline Age 36 to 49 & $\begin{array}{l}10.63 * * * \\
(2.74)\end{array}$ & $\begin{array}{l}10.99 * * * \\
(2.92)\end{array}$ & $\begin{array}{l}21.78 * * * \\
(2.97)\end{array}$ \\
\hline Age 50 to 64 & $\begin{array}{c}2.22 \\
(0.53)\end{array}$ & $\begin{array}{c}2.71 \\
(0.66)\end{array}$ & $\begin{array}{c}5.85 \\
(0.94)\end{array}$ \\
\hline Age $65+$ & $\begin{array}{c}1.51 \\
(0.30)\end{array}$ & $\begin{array}{c}2.66 \\
(0.56) \\
\end{array}$ & $\begin{array}{c}4.08 \\
(0.54) \\
\end{array}$ \\
\hline Married or cohabitating & $\begin{array}{l}7.36^{*} \\
(1.65)\end{array}$ & $\begin{array}{c}5.51 \\
(1.27)\end{array}$ & $\begin{array}{l}10.46^{*} \\
(1.71)\end{array}$ \\
\hline Children & $\begin{array}{l}-2.21 \\
(-1.11)\end{array}$ & $\begin{array}{l}-1.36 \\
(-0.69)\end{array}$ & $\begin{array}{c}-0.48 \\
(-0.16)\end{array}$ \\
\hline \multicolumn{4}{|c|}{ Reference is first quartile group of household income ${ }^{\mathrm{a})}$} \\
\hline Second quartile group & $\begin{array}{l}-4.79 \\
(-1.00)\end{array}$ & $\begin{array}{l}-3.46 \\
(-0.78)\end{array}$ & $\begin{array}{l}-5.41 \\
(-0.77)\end{array}$ \\
\hline Third quartile group & $\begin{array}{l}-6.21 \\
(-1.45)\end{array}$ & $\begin{array}{c}-4.01 \\
(-0.87)\end{array}$ & $\begin{array}{l}-11.70 \\
(-1.55)\end{array}$ \\
\hline Fourth quartile group & $\begin{array}{c}-6.33 \\
(-1.33)\end{array}$ & $\begin{array}{c}-5.12 \\
(-1.07)\end{array}$ & $\begin{array}{l}-11.87 \\
(-1.46)\end{array}$ \\
\hline Owner of primary home & $\begin{array}{c}15.52 * * * \\
(3.03)\end{array}$ & $\begin{array}{c}15.29 * * * \\
(2.88)\end{array}$ & $\begin{array}{c}25.74 * * * \\
(2.89)\end{array}$ \\
\hline \multicolumn{4}{|l|}{ Reference is summer cottage } \\
\hline $\begin{array}{l}\text { Second home is an apartment/ } \\
\text { time share }\end{array}$ & $\begin{array}{l}9.11 * * * \\
(2.96)\end{array}$ & $\begin{array}{l}7.71 * * * \\
(2.77)\end{array}$ & $\begin{array}{l}17.35 * * * \\
(2.80)\end{array}$ \\
\hline Age of second home & $\begin{array}{c}0.21 * * * \\
(4.89)\end{array}$ & $\begin{array}{c}0.14 * * * \\
(3.17)\end{array}$ & $\begin{array}{c}0.26 * * * \\
(2.81)\end{array}$ \\
\hline Living area of second home & $\begin{array}{c}0.43 * * * \\
(2.58)\end{array}$ & $\begin{array}{l}0.45^{* *} \\
(2.94)\end{array}$ & $\begin{array}{l}0.63 * * \\
(2.13)\end{array}$ \\
\hline Living area of second home squared & $\begin{array}{l}-0.00 * * \\
(-2.01)\end{array}$ & $\begin{array}{l}-0.00 * * \\
(-2.05)\end{array}$ & $\begin{array}{l}-0.00 \\
(-1.19)\end{array}$ \\
\hline Second home in different region & $\begin{array}{c}-6.31 \\
(-1.42)\end{array}$ & $\begin{array}{l}-2.00 \\
(-0.45)\end{array}$ & $\begin{array}{c}-4.20 \\
(-0.59)\end{array}$ \\
\hline Second home in town/city & $\begin{array}{c}5.14 \\
(1.29) \\
\end{array}$ & $\begin{array}{l}6.47 * \\
(1.73)\end{array}$ & $\begin{array}{l}20.76^{*} \\
(1.97)\end{array}$ \\
\hline \multicolumn{4}{|l|}{ Reference is LTV for second home $=0$} \\
\hline LTV $0-0.4$ & $\begin{array}{c}6.72 \\
(1.24)\end{array}$ & $\begin{array}{c}5.31 \\
(1.00)\end{array}$ & $\begin{array}{c}5.24 \\
(0.90)\end{array}$ \\
\hline LTV 0.4-0.8 & $\begin{array}{c}13.82 * * * \\
(2.51)\end{array}$ & $\begin{array}{c}14.14 * * * \\
(2.58)\end{array}$ & $\begin{array}{c}16.88 * * \\
(2.49)\end{array}$ \\
\hline LTV $>0.8$ & $24.81 * * *$ & $20.56 * * *$ & $26.59 * * *$ \\
\hline
\end{tabular}


$(3.88)$

\begin{tabular}{lccc} 
Rent per week for second home & $-0.51 * * *$ & $-0.61 * * *$ \\
Constant & & $(-4.21)$ & $(-3.50)$ \\
& $-35.99 * * *$ & $-25.04 *$ & $-51.22 * *$ \\
Number of observations & $(2.67)$ & $(1.95)$ & $(-2.31)$ \\
$\mathrm{F}$ & 94 & 93 & 93 \\
$\mathrm{R}^{2}$ (pseudo for tobit) & $17.52 * * *$ & $34.39 * * *$ & 13.16 \\
\hline
\end{tabular}

Notes: Two robust OLS and one tobit regression among households with one second home that is let. Letting creates income, which potentially may give endogeneity. However, the respondents are asked about last month's income, and we do not think that income from letting is included in the response. The tobit regression includes 49 right censored observations for number of let weeks above 52. a) See table A1 in the appendix for the cutoff values.

Source: Data from a survey conducted in the midsummer of 2012 and administrative register data.

The second regression in table 7 includes the weekly rent reported by the respondents as explanatory variable. It comes out highly significant with a negative coefficient. One interpretation of this could be that a high rent reduces the demand from potential tenants leading to fewer weeks of letting over a year. Another interpretation could be that the weekly rent for the home is a proxy for the quality of the home and thereby for the amount of housing units in addition to the number of square meters living room. A high rent indicates higher quality of the square meters or a better location, e.g. proximity to the sea. The negative coefficient then shows that better quality second homes are more demanded by their owners than by potential tenants and are so let for fewer weeks.

A high number of observations of letting over the whole year, i.e. 52 weeks, constitutes a potential problem for the OLS regressions. More than half of the households with one second home that is let report that this is for the whole year. Amongst owners of second apartments, 88 per cent let all year round, and all with second joint ownership and timeshare who let, report that the second home is let all the 52 weeks. The 52 weeks could be a corner solution for many of the respondents who may also have let 52 weeks at a lower weekly rent. ${ }^{11}$ If so, they would optimally let more than 52 weeks at the going rent. Following Fair (1978), a tobit regression will be appropriate and is run with the results shown in the last column of table

\footnotetext{
${ }^{11}$ If the question had been: How many weeks has the home been let over the last three years, the maximum number of weeks would have been 156 weeks, and fewer may have reported this number of weeks.
} 
7. ${ }^{12}$ The tobit regression keeps the signs of the OLS regressions, but with bigger coefficients in most cases.

\section{Income elasticities for housing demand}

While many researchers (see Mayo 1981, Goodman and Kawai 1984, Malpezzi and Mayo 1987, Goodman 1988, and 1990 and Hansen et al. 1996, and 1998) have been looking for income elasticities of primary housing demand, we have only found Belsky et al. (2007) and Di (2009) who study the effect of second homeownership on the income elasticity for housing demand. Belsky et al. (2007) posit (p.380) "that consumption of primary home is the first priority because that is where homeowners spend most of the time. Therefore an incremental dollar will contribute more to consumption of a primary home than of a second home." They use data from the American Housing Survey and take the value of homes as proxy for the consumption of housing. Their estimations use home value as dependent variable and show that the second homeowners' income elasticities for all housing are lower than the elasticities for primary housing, which is taken as support for their hypothesis. However, it could also be that primary housing is the needed shelter for households, whereas second housing is something extra, which is more similar to luxury goods. If so, the demand for second housing should have the highest income elasticity.

Compared to most consumption goods, there is a reduced continuity in the consumption of owned second housing. Buying a second home will furthermore reduce the possibility for consumption of other substituting "vacation" goods for financially constrained households. Many households will have to choose between either buying a second home or buying a big pleasure boat, a camper, going on luxury cruises and golf journeys, etc. In our analysis we do not include the second housing consumption of households that could potentially be owners of second homes, but prefer to rent, and this may increase income elasticities for second housing demand in income intervals where households "jump" into second ownership. We have no data that allow us to include second housing consumption by households who rent second homes.

\footnotetext{
${ }^{12}$ Our observations in table 7 are second homeowners who let. This excludes owners who let zero weeks at the going rent but also would let zero weeks at higher rents.
} 
21 per cent of the Danish owners of primary homes in the survey own a second home, and the same is true for 12 per cent of coop owners and tenants. In the following analyses, we again exclude households with more than one second home, partly because our data become less precise when more second homes are involved, and partly because it can be argued that ownership of more than one second home typically involves investment motives, which should not be mixed up with consumption.

Belsky et al. (2007) and Di (2009) assume that the value of each home reflects the embedded amount of housing units, and use locational dummies to account for spatial price differences. Following Blackley et al. (1986), we estimate a hedonic regression and use the estimates to calculate the "price" for a standard primary home based on the median values of housing characteristics and controlling for location ${ }^{13}$ differences. By dividing the reported home values by this "price" of a standard housing unit, we get the quantity of primary housing consumption. The same procedure was used to calculate the quantity of second housing consumption by owners of second homes. The regional prices differ between the two types of homes. To account for regional price differences when total demand for homes is regressed, we include a price indicator for each region that is based on a weighted average of the prices of primary and second homes. The appendix documents the method.

We use a log-linear specification to estimate housing demand:

$$
\ln \left(\text { housing }_{i}\right)=\beta_{0}+\beta_{1} \ln \left(\text { income }_{i}\right)+\beta_{2} \ln \left(\text { price }_{i}\right)+\sum_{i}^{I} \beta_{i} X_{i}+\epsilon_{i}
$$

The variable housing $i$, measures the quantity of housing demanded, either for primary housing, secondary housing, or both. To account for regional price differences we include price $_{i}$, which is a price indicator for each region as explained above. The variable income $_{i}$ is permanent household income; $X_{i}$ is a vector of various household characteristics, and $\varepsilon_{i}$ is a random error term.

Table 8 shows four different regressions for housing demand that differ in the type of dependent variables and subsamples used for estimation. Because our data set for primary tenants is small, we have confined our analysis to owners of primary homes alone.

\footnotetext{
${ }^{13}$ Denmark is officially divided in to five regions, ten "landsdele" and 98 municipalities. The spatial entity landsdel is used for statistical purposes. The population size in landsdele ranges between 225 and 630 thousands except for one very small landsdel. The number of square kilometers ranges between 170 and 8,800.
} 
Table 8: OLS regressions of In of the quantity of housing demanded

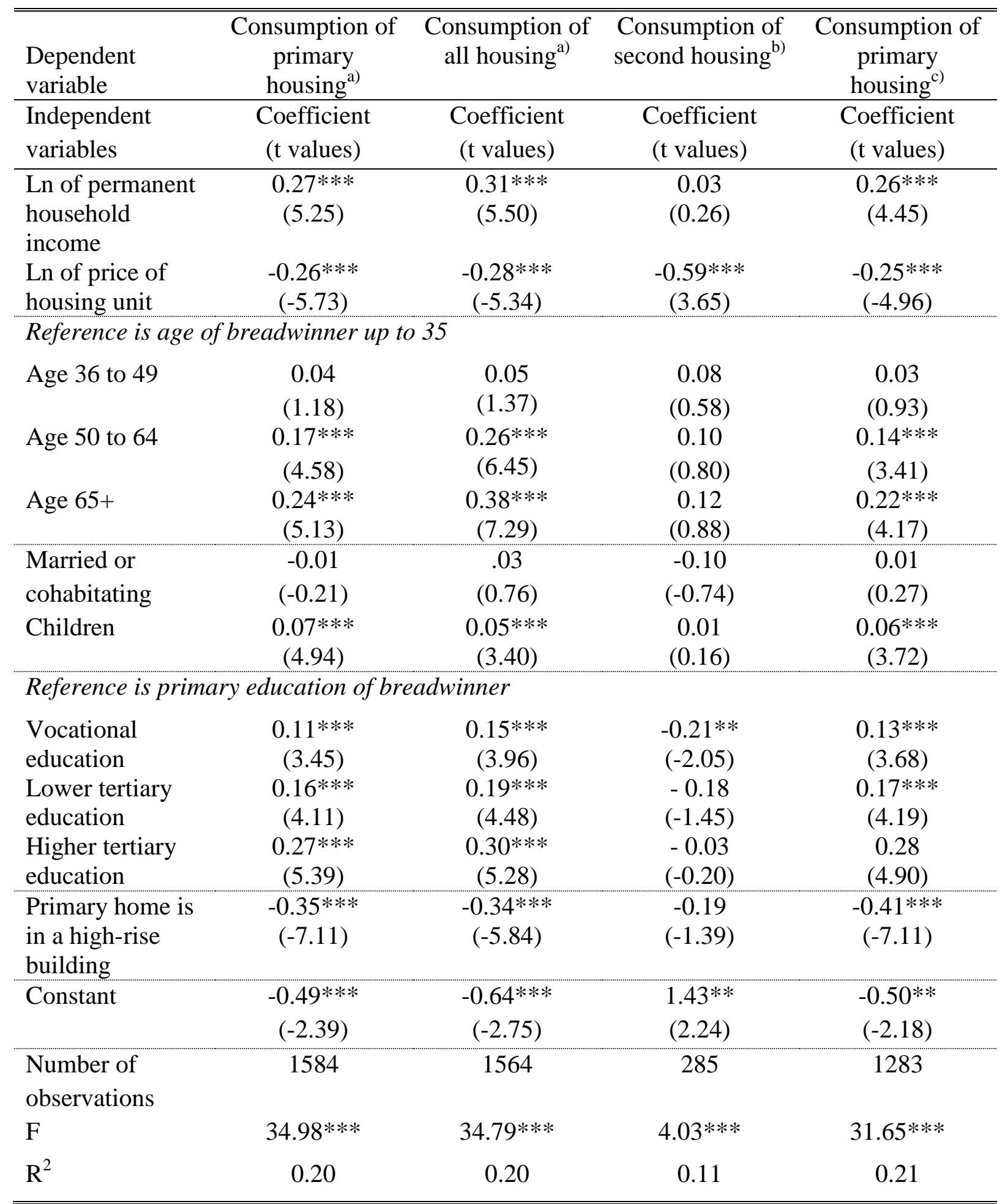

Notes: Robust OLS regressions. a) Based on sample of all primary homeowners. b) Subsample of second homeowners. c) Subsample of primary homeowners without second home.

Source: Data from a survey conducted in the midsummer of 2012 and register data. 
The income elasticities are in the low end of the range of reported elasticities in Mayo (1981), and this is also the case for the price elasticities. The first regression shows that the income elasticity for primary housing demand is 0.27 , which increases to 0.31 if we consider consumption for both primary and second housing. Implicitly, this pattern points towards higher income elasticities for second housing, but the third regression on second housing demand alone does not confirm this. Another way to go is to compare the income elasticities for primary housing demand between owners and non-owners of second homes. The last regression in table 8 is for primary homeowners who do not own second homes. Non owners of second homes appear to have an income elasticity for housing equal to 0.26 , which is slightly lower than for all primary homeowners. This result runs counter to the results of Belsky et al. (2007) and Di (2009) who - using an interaction variable - find the highest income elasticity for primary housing demand among non-owners of second homes. The expected negative correlation between the prices of housing and demand is found in all four regressions.

The regressions using consumption of primary or both types of housing show that the household's (breadwinner's) age is important. A higher age has a strong positive connection with the amount of housing being consumed. No relation is found for marriage and cohabitation, while having children is positively associated with housing consumption. Higher education is also positively related to primary and total housing consumption. Households who have settled in a high-rise building have lower demand for housing. To dig deeper into the matter, we have run the same set of regressions for housing demand, but with the households being split into three income groups. The results are presented in table 9, where, for clarity reasons, only the income elasticities are reported. 
Table 9: Income elasticities of housing demand by income groups

\begin{tabular}{|c|c|c|c|c|c|}
\hline \multirow{3}{*}{ Primary housing demand } & & \multicolumn{4}{|c|}{ Household permanent income level } \\
\hline & & \multirow[t]{2}{*}{$\begin{array}{c}\text { All } \\
\text { incomes }\end{array}$} & \multirow[t]{2}{*}{$\begin{array}{l}\text { Low } \\
\text { income }\end{array}$} & \multirow[t]{2}{*}{$\begin{array}{l}\text { Middle } \\
\text { income }\end{array}$} & \multirow[t]{2}{*}{$\begin{array}{l}\text { High } \\
\text { income }\end{array}$} \\
\hline & & & & & \\
\hline All primary homeowners & $\begin{array}{c}\text { Elasticity } \\
\mathrm{R}^{2} \\
\mathrm{~N}\end{array}$ & $\begin{array}{c}0.27 * * * \\
0.20 \\
1584\end{array}$ & $\begin{array}{l}0.17 \\
0.17 \\
403 \\
\end{array}$ & $\begin{array}{c}0.51 * * * \\
0.19 \\
525\end{array}$ & $\begin{array}{l}0.28 \\
0.15 \\
656\end{array}$ \\
\hline $\begin{array}{l}\text { Primary homeowners without } \\
\text { second homes }\end{array}$ & $\begin{array}{c}\text { Elasticity } \\
\mathrm{R}^{2} \\
\mathrm{~N}\end{array}$ & $\begin{array}{c}0.26 * * * \\
0.21 \\
1283\end{array}$ & $\begin{array}{l}0.19 \\
0.18 \\
328\end{array}$ & $\begin{array}{c}0.42 * * \\
0.22 \\
425\end{array}$ & $\begin{array}{c}0.53 * \\
0.16 \\
530\end{array}$ \\
\hline $\begin{array}{l}\text { Primary homeowners with } \\
\text { second homes }\end{array}$ & $\begin{array}{c}\text { Elasticity } \\
\mathrm{R}^{2} \\
\mathrm{~N}\end{array}$ & $\begin{array}{c}0.27 * * \\
0.17 \\
281 \\
\end{array}$ & $\begin{array}{c}-0.05 \\
0.19 \\
69 \\
\end{array}$ & $\begin{array}{c}0.80 * * \\
0.27 \\
96 \\
\end{array}$ & $\begin{array}{l}0.00 \\
0.11 \\
116 \\
\end{array}$ \\
\hline All housing demand & & & & & \\
\hline All primary homeowners & $\begin{array}{c}\text { Elasticity } \\
\mathrm{R}^{2} \\
\mathrm{~N} \\
\end{array}$ & $\begin{array}{c}0.31 * * * \\
0.20 \\
1564 \\
\end{array}$ & $\begin{array}{l}0.17 \\
0.17 \\
397 \\
\end{array}$ & $\begin{array}{c}0.49 * * * \\
0.20 \\
521 \\
\end{array}$ & $\begin{array}{c}0.29 \\
0.16 \\
646 \\
\end{array}$ \\
\hline Second housing demand & & & & & \\
\hline $\begin{array}{l}\text { Primary homeowners with } \\
\text { second homes }\end{array}$ & $\begin{array}{c}\text { Elasticity } \\
\mathrm{R}^{2} \\
\mathrm{~N}\end{array}$ & $\begin{array}{l}0.03 \\
0.11 \\
285 \\
\end{array}$ & $\begin{array}{c}-0.33 \\
0.18 \\
69 \\
\end{array}$ & $\begin{array}{c}0.59 \\
0.22 \\
97\end{array}$ & $\begin{array}{c}0.33 \\
0.10 \\
119 \\
\end{array}$ \\
\hline Summer cottage demand & & & & & \\
\hline $\begin{array}{l}\text { Primary homeowners with } \\
\text { summer cottages }\end{array}$ & $\begin{array}{c}\text { Elasticity } \\
\mathrm{R}^{2} \\
\mathrm{~N}\end{array}$ & $\begin{array}{c}-0.00 \\
0.11 \\
238 \\
\end{array}$ & $\begin{array}{c}-0.15 \\
0.09 \\
60\end{array}$ & $\begin{array}{c}0.49 \\
0.22 \\
84 \\
\end{array}$ & $\begin{array}{c}0.06 \\
0.15 \\
94 \\
\end{array}$ \\
\hline
\end{tabular}

Notes: Robust OLS regressions. The middle permanent income level ranges from DKK 367,350 to DKK 651,360

Source: Data from a survey conducted in the midsummer of 2012 and register data.

The income elasticity for primary housing demand is highest for the middle income group. Elasticities for primary homeowners without second homes follow the usual pattern with monotonically increasing elasticities for higher income groups, and the estimated elasticities are in close line with those found by Hansen et al. (1998). However, when we only look at demand for primary housing among owners of second homes, we find a high income elasticity for the middle income group and zero elasticity for the outer income groups, and this exceptional pattern is the reason why the usual monotonic increase in elasticities over income is broken both for primary and for all housing demand. This is an interesting result partly because it again runs counter to Belsky et al. (2007) and Di's (2009) results, and partly 
because it indicates that a high level of permanent income is used to raise housing consumption especially among second homeowners with middle incomes.

The estimation of income elasticities for second housing is hampered by a low number of observations. No significant positive income elasticity for second homeownership is found, but breaking the owners into groups according to their income level indicates the highest elasticity for the middle income group. Table 10 shows the median housing consumption within the three income groups. Homeowners without second homes have a comparatively low level of consumption that increases with income. Homeowners with second homes consume the double amount of housing and also have a higher level of primary housing. They have a marked jump in primary housing consumption from the low to the middle income level and a modest increase from the middle to the high income level. They have a higher median primary housing consumption in the middle income group than the primary housing consumption in the high income group among homeowners with no second home. Thus, saturation may be the reason for second homeowners' low income elasticity in the high income group.

Table 10: Median consumed housing units by primary homeowners

\begin{tabular}{|c|c|c|c|c|c|}
\hline $\begin{array}{l}\text { Number of housing units based } \\
\text { on reported values divided by } \\
\text { hedonic prices }\end{array}$ & & $\begin{array}{c}\text { All } \\
\text { incomes }\end{array}$ & $\begin{array}{c}\text { Low } \\
\text { income }\end{array}$ & $\begin{array}{l}\text { Middle } \\
\text { income }\end{array}$ & $\begin{array}{l}\text { High } \\
\text { income }\end{array}$ \\
\hline All homeowners & $\begin{array}{l}\text { Total } \\
\text { housing }\end{array}$ & 1.179 & 0.982 & 1.127 & 1.310 \\
\hline $\begin{array}{l}\text { Homeowners without second } \\
\text { homes }\end{array}$ & $\begin{array}{l}\text { Primary } \\
\text { housing }\end{array}$ & 1.064 & 0.851 & 0.982 & 1.197 \\
\hline \multirow[t]{3}{*}{ Homeowners with second homes } & $\begin{array}{l}\text { Primary } \\
\text { housing }\end{array}$ & 1.228 & 0.958 & 1.235 & 1.310 \\
\hline & $\begin{array}{l}\text { Second } \\
\text { housing }\end{array}$ & 0.764 & 0.766 & 0.684 & 0.764 \\
\hline & $\begin{array}{l}\text { Total } \\
\text { housing }\end{array}$ & 2.144 & 1.879 & 2.192 & 2.172 \\
\hline
\end{tabular}

Notes: The middle permanent income level ranges from DKK 367,350 to DKK 651,360.

Source: Data from a survey conducted in the midsummer of 2012 and register data.

Second homeowners' consumption of second housing is lower than their consumption of primary housing, and here there is literally no difference between the income groups. One explanation for the high consumption level in the low income group can be that we have 
many old-age retired owners in this group. Official statistics show that 25 per cent of the summer cottages are owned by pensioners and other persons outside the labor market and that 20 per cent are inherited. Looking at the middle income group, the median consumption level is low, but table 9 showed that a high positive income elasticity can be estimated for this group. As for primary housing consumption, saturation may play a role in the high income group. Finally, our estimated elasticities for second housing demand could be biased upwards in income intervals where households "jump" into second ownership. If we were able to include rented second housing demand, the elasticities may have been lower.

\section{Conclusion}

An increasing number of households consume housing beyond their primary home and become owners of second homes. According to a Danish survey from the summer of 2012, 36 per cent of the owners of second homes let them out for shorter or longer periods. Both the ownership of second homes and the letting are important for the tourism industry and have implications for the building industry and for planners of land and infrastructure.

The present study shows that the probability of second homeownership is positively associated with the age of the household's breadwinner as well as with marriage and cohabitation, and negatively correlated with children in the household. A high income increases the probability of owning, and so does higher educational attainment of the breadwinner. When compared to tenants and coop owners of primary homes, homeowners have a higher probability for owning second homes and even more if the primary home is in a high-rise building.

Letting the second home decreases with the breadwinner's age and the household's income. Primary homeowners are more inclined to let, and letting increases with the loan-to-value rate of the second home. Letting is positively associated with the size of the second home and with a location of the home in a town or city, where most second apartments are located. Among those who let their second homes, the number of weeks let per year is highest for the age group 35 to 49. Primary homeowners let more weeks, and the weeks increase with the age and size of the second home. Second homes with joint ownership and timeshare are let for more weeks. 
Economic literature on the income elasticity of housing demand when second housing is involved is scarce. Like in earlier studies, we found monotonically increasing income elasticities over income levels for housing demand for the big group of primary homeowners without second homes. But owners of second homes had the highest income elasticity in the middle income group and zero elasticity for the outer income groups. Our estimations of income elasticities for second housing did not produce statistically significant results, but again showed the highest elasticities for the middle income group.

We conclude that income elasticities for owners of second homes deviate from the usual pattern for primary homeowners. The elasticity for the middle income group may be high because it is more important for second homeowners in this group to keep up with or surpass the Joneses, while this is less pronounced for high income households who have reached a level of housing consumption that is close to their saturation level.

\section{Appendix}

Table A1: Summary statistics for all households in the survey

\begin{tabular}{lcccc}
\hline Variable & Mean & Min & Max & Observations \\
\hline Age of breadwinner & 52.1 & 26 & 87 & 2385 \\
Married or cohabitating & 0.65 & 0 & 1 & 2385 \\
Have children bellow age 18 & 0.68 & 0 & 1 & 2366 \\
\hline Annual household income in DKK & 592,233 & 6,000 & $6,600,000$ & 2139 \\
\hline First quartile: up to 300,000 & 0.29 & 0 & 1 & 2139 \\
Second quartile: 300,001 to 504,000 & 0.24 & 0 & 1 & 2139 \\
Third quartile: 504,001 to 756,000 & 0.25 & 0 & 1 & 2139 \\
Fourth quartile: 756,001+ & 0.23 & 0 & 1 & 2139 \\
\hline Predicted annual permanent income & 511,227 & 110,516 & $11,901,170$ & 2332 \\
\hline Owner of primary home & 0.73 & 0 & 1 & 2366 \\
Coop owner of primary home & 0.08 & 0 & 1 & 2366 \\
Tenant of primary home & 0.19 & 0 & 1 & 2366 \\
\hline Primary education of breadwinner & 0.23 & 0 & 1 & 2358 \\
Vocational education of breadwinner & 0.44 & 0 & 1 & 2358
\end{tabular}




\begin{tabular}{lcccc} 
Lower tertiary education of breadwinner & 0.20 & 0 & 1 & 2358 \\
Higher tertiary education of breadwinner & 0.12 & 0 & 1 & 2358 \\
\hline Has a second home & 0.19 & 0 & 1 & 2385 \\
LTV for primary home & 0.72 & 0 & 1.90 & 1482 \\
LTV: 0.00 to 0.80 & 0.58 & 0 & 1 & 1482 \\
LTV: 0.81 to 1.00 & 0.25 & 0 & 1 & 1482 \\
LTV: 1.01 to 1.20 & 0.12 & 0 & 1 & 1482 \\
LTV: 1.21 to $\max$ & 0.05 & 0 & 1 & 1482 \\
\hline
\end{tabular}

Notes: The table shows variables that are used in the regressions in the paper. a) Predictions based on the regression in table A2.

Source: Data from a survey conducted in the midsummer of 2012 and administrative register data.

\section{Permanent income equation}

Table A2: OLS regressions of In of annual household income for the prediction of ln of permanent income

\begin{tabular}{lc}
\hline \hline Variable & $\begin{array}{c}\text { Coefficient } \\
(\mathrm{t} \text { values })\end{array}$ \\
\hline Age & $0.03^{* * *}$ \\
& $(5.01)$ \\
Age squared & $-0.000^{* * *}$ \\
& $(-4.59)$ \\
Female breadwinner & $-0.12^{* * *}$ \\
& $(-5.20)$ \\
Immigrant & $-0.21^{* * *}$ \\
& $(-4.57)$ \\
\hline Reference is second and lower education & \\
Lower tertiary education of breadwinner & $0.14 * * *$ \\
& $(4.90)$ \\
Higher tertiary education of breadwinner & $0.37 * * *$ \\
& $(11.51)$ \\
\hline Reference is working single & \\
Single unemployed or pre pensioner & $-0.75^{* * *}$ \\
Single pensioner & $(-10.59)$ \\
Cohabitating couple, both employed & $-0.66^{* * *}$ \\
Cohabitating couple, one employed & $(-9.85)$ \\
Cohabitating couple, both unemployed or not in the labor force & $0.60^{* * *}$ \\
& $(20.58)$ \\
& $0.25^{* * *}$ \\
& $(6.23)$ \\
& $-0.17^{* * *}$ \\
& $(-3.51)$
\end{tabular}




\begin{tabular}{lc} 
Living in the city of Copenhagen & $0.08 * * *$ \\
& $(2.63)$ \\
Constant & $2.97 * * *$ \\
& $(18.86)$ \\
Number of observations & 2041 \\
$\mathrm{~F}$ & $205.90 * * *$ \\
$\mathrm{R}^{2}$ & 0.48 \\
\hline \hline
\end{tabular}

Notes: Robust OLS regression. Ln of income is chosen as dependent variable because a Box-Cox regression gives a $\lambda$ of -0.04 , which is close to zero.

Source: Data from a survey conducted in the midsummer of 2012 and administrative register data.

\section{Calculating housing quantities}

Housing quantities are calculated by the use of the hedonic regression for primary and second homes shown in table A3. Table A3 also gives the median values of the variables used to calculate the price of a "median" home, i.e. a standard home.

A division of the self-reported market values of primary homes with the median primary home price in each part of the country is used to calculate the amount of housing units embedded in each primary home, which is a proxy for the consumption of primary housing. A similar procedure is followed to calculate the price and quantities of consumption of second housing.

The logarithm of the calculated consumption of housing units is entered as the dependent variable in the regressions in table 8 and 9 in the paper.

Table A3: Hedonic regressions of In of primary and second home values

\begin{tabular}{lccc}
\hline \hline & & \multicolumn{2}{c}{ Median values } \\
\cline { 3 - 4 } Independent variable & $\begin{array}{c}\text { Coefficient } \\
\text { (t values) }\end{array}$ & Primary homes & Second homes \\
\hline Living area & $0.02 * * *$ & 13.85 & 7.19 \\
Living area squared & $(12.32)$ & & 51.84 \\
Age of home in decades & $-0.002^{* * *}$ & 191.83 & 5.00 \\
Age squared & $(-6.93)$ & & \\
& $-0.03 * * *$ & 5.20 & 25.00 \\
Reference is external walls of bricks & $(-3.31)$ & & \\
\hline
\end{tabular}




$\begin{array}{llll}\text { External walls of tree or half-timbering } & 0.12^{*} & 0 & 0 \\ & (1.94) & & \\ \text { Interaction with second home } & -0.45^{* * *} & & 0 \\ & (-4.41) & & 0 \\ \text { External walls of other material }^{\text {a) }} & -0.09 * & 0 & \end{array}$

Reference is roof of tile, concrete stone or thatched roof

\begin{tabular}{lccc} 
Roof of other material & $-0.14 * * *$ & 1 & 1 \\
& $(-6.36)$ & & 0 \\
Has district heating & $0.14 * * *$ & 1 & \\
& $(4.06)$ & & 0 \\
Interaction with second home & $-0.73 * * *$ & & \\
& $(-6.42)$ & & 1 \\
Located in multifamily building & $-0.13 * * *$ & 0 & \\
& $(-2.66)$ & & 0 \\
\hline Is a second home & $0.81 * * *$ & $(9.90)$ &
\end{tabular}

Reference is city and suburbs of Copenhagen

North Zealand

Interaction with second home

Other Zealand ${ }^{\text {b) }}$

Interaction with second home

Funen

Interaction with second home

South Jutland

East Jutland

Interaction with second home

West Jutland

North Jutland
$-0.18 * * *$

$-0.49 * * *$

$(-3.24)$

$-0.65 * * *$

$(-15.26)$

$-0.23 * * *$

$(-2.94)$

$-0.65 * * *$

$(-14.15)$

$-0.34 * * *$

$(-3.35)$

$-0.73 * * *$

(-16.41)

$-0.50 * * *$

(-9.95)

$-0.33 * * *$

$(-3.35)$

$-0.820 * * *$

(-17.00)

$-0.81 * * *$

(-17.93)

$13.78 * * *$

(145.97)

1989

1634

355

$77.56 * * *$

0.45 
Notes: Robust OLS regressions. a) Other material may be lightweight concrete, fiber cement, concrete panel, metal plate, pvc, and glass. b) Includes Bornholm. Logarithmic transformation of the dependent variable is chosen because a Box-Cox regression gives a $\lambda$ of 0.14 , which is close to zero.

Source: Data from a survey conducted in the midsummer of 2012 and administrative register data.

\section{References}

Belsky, E.S., Di, Z.X., \&. McCue, D. (2007). Multiple-Home Ownership and the Income Elasticity of Housing Demand. In Gregory K. Ingram, G. K. \& Hong Y.-H. (eds.) Land policies and their outcomes. Cambridge, Mass.: Lincoln Institute of Land Policy, 372-400.

Bieger, T., Beritelli, P., Weinert, R., \& Widmann, F. (2006). Demographic and economic change and their impact on the lease of second homes in Swiss tourist destinations. In Weiermair K., Pechlaner H. and Bieger T., (eds.) Time Shift, Leisure and Tourism. Impacts of Time Allocation on Successful Products and Services. Berlin: Erich Schmidt Verlag. p. 119130.

Bieger, T., Beritelli, P. \& Weinert, R. (2007). Understanding second home owners who do not rent-Insights on the proprietors of self-catered accommodation. International Journal of Hospitality Management, 26(2), 263-276.

Blackley, D. M., Follain, J. R., \& Lee, H. (1986). Evaluation of hedonic price indexes for thirty-four large SMSAs. American Real Estate and Urban Economics Association Journal, 14(2), 179-205.

Carliner, M. (2007). Multiple-home ownership and the income elasticity of housing demand: Commentary. In Gregory K. Ingram, G. K. \& Hong Y.-H. (eds.) Land policies and their outcomes. Cambridge, Mass.: Lincoln Institute of Land Policy, 401-404.

Cho, S., Newman, D. H., \& Wear, D. N. (2003). Impacts of second home development on housing prices in the Southern Appalachian Highlands. Review of Urban and Regional Development Studies, 15(3), 208-225.

Di, Z. X., McArdle, N., Masnick, G. S. (2001) Second Homes: What, How Many, Where and Who. Working Parer series N01-2. Joint Center for Housing Studies. Harvard University.

Di, Z. X. (2009). Does second-home ownership affect primary housing demand? Housing Studies, 24(3), 321-332.

Fair, R. C. (1978). A theory of extramarital affairs. Journal of Political Economy, 86(1), 4561.

Goodman, A. C., \& Kawai, M. (1984). Replicative evidence on the demand for owneroccupied and rental housing. Southern Economic Journal, 50(4), 1036-1057. 
Goodman, A. C. (1988). An econometric model of housing price, permanent income, tenure choice, and housing demand. Journal of Urban Economics, 23(3), 327-353.

Goodman, A. C. (1990). Demographics of individual housing demand. Regional Science and Urban Economics, 20(1), 83-102.

Guisan, M., \& Aguayo, E. (2010). Second homes in the Spanish regions: Evolution in 20012007 and impact on tourism, GDP and employment. Regional and Sectoral Economic Studies, 10(2), 83-94.

Hansen, J. L., Formby, J. P., \& Smith, W. J. (1996). The income elasticity of demand for housing: Evidence from concentration curves. Journal of Urban Economics, 39(2), 173-192.

Hansen, J. L., Formby, J. P., \& Smith, W. J. (1998). Estimating the income elasticity of demand for housing: A comparison of traditional and lorenz-concentration curve methodologies. Journal of Housing Economics, 7(4), 328-342.

Hoogendoorn, G., Mellett, R., \& Visser, G. (2007). Second Homes Tourism in Africa: Reflections on the South African experience. Urban Forum, 16(2-3), 112-154 .

Hoogendoorn, G., \& Visser, G. (2010). The role of second homes in local economic development in five small South African towns. Development Southern Africa, 27(4), 547562.

Huang, Y., \& Yi, C. (2011). Second home ownership in transitional urban China. Housing Studies, 26(3), 423-447.

Malpezzi, S., \& Mayo, S. K. (1987). The demand for housing in developing countries: Empirical estimates from household data. Economic Development and Cultural Change, 35(4), 687-721.

Mayo, S. K. (1981). Theory and estimation in the economics of housing demand. Journal of Urban Economics, 10(1), 95-116.

Marcouiller, D.W., W.F. Gartner \& A. Chara (2013). Recreational Homes and Planning in Gateway Communities: A Literature Review. Working Paper 13-2. University of Wisconsin. Madison. Department of Urban and Regional Planning.

McIntyre, N., Williams, D. \& McHugh, K. (2006). Multiple dwelling: prospect and retrospect. In: N. McIntyre, D. Williams \& K. McHugh (eds.) Multiple Dwelling and Tourism: Negotiating Place, Home, and Identity, pp. 313-322 (Cambridge MA: CABI Publishing).

Modenes Cabrerizo, J. A., \& Lopez Colas, J. (2007). Second homes in Spain: Sociodemographic and geographical profiles. Population, 62(1), 157-171. 
Salo, A., \& Garriga, A. (2011). The second-home rental market: A hedonic analysis of the effect of different characteristics and a high-market-share intermediary on price. Tourism Economics, 17(5), 1017-1033.

Salo, A., Garriga, A., Rigall-I-Torrrent, R., Vila, M., \& Sayeras, J. M. (2012). Differences in seasonal price patterns among second home rentals and hotels: Empirical evidence and practical implications. Tourism Economics, 18(4), 731-747.

Torres, E., \& Dominguez-Menchero, J. (2006). The impact of second homes on local taxes. Fiscal Studies, 27(2), 231-250. 